\title{
STUDY OF ARSENIC EXPOSURE IN ORAL/OROPHARYNGEAL CARCINOMA IN WEST BENGAL
}

\section{PRITHA PAL ${ }^{1}$, RANJAN RAYCHOWDHURY ${ }^{2}$, TUPHAN KANTI DOLAI ${ }^{3}$, SANCHITA ROY $^{4}$, RININI DASTIDAR, and AJANTA HALDER ${ }^{1}$}

${ }^{1}$ Vivekananda Institute of Medical Sciences, Kolkata, India

Department of Genetics

${ }^{2}$ Vivekananda Institute of Medical Sciences, Kolkata, India

Department of ENT-Head and Neck Surgery

${ }^{3}$ Nil Ratan Sarkar Medical College and Hospital, Kolkata, India

Department of Haematology

${ }^{4}$ Institute of Post Graduate Medical Education and Research, Kolkata, India

Department of Anatomy

${ }^{5}$ Vivekananda Institute of Medical Sciences, Kolkata, India

Department of Biochemistry

\begin{abstract}
Objectives: To study any possible correlation between arsenic toxicity and the development of oral carcinoma in West Bengal population. Material and Methods: Ethical clearance for this study was obtained from the Vivekananda Institute of Medical Sciences. Out of 30785 patients attending our hospital from November 2012 to July 2015, 107 cases and 50 control individuals were selected. The hair and buccal smear samples were obtained upon their consent for the purpose of the analysis of arsenic count and cytogenetic damage, respectively. Results: Ninety-six percent of cases came from the highly arsenic affected districts and $81.3 \%$ showed their arsenic count above the safe limit $(0.8 \mu \mathrm{g} / \mathrm{g})$ whereas $96 \%$ of the controls' arsenic count was within the safe limit. The study showed a significant difference of the micronuclei and apoptosis frequency between the cases and controls. Conclusions: The difference of micronuclei and apoptosis frequency between cases and controls was significant. The maximum number of cases came from highly arsenic affected areas and a higher percentage of cases showed elevated arsenic count, as compared to controls, which may indicate a possible link between arsenic toxicity and this disease. However, a larger sample size is required for a proper correlation. Int J Occup Med Environ Health 2017;30(2):271-279
\end{abstract}

Key words:

Apoptosis, Risk factor, Micronuclei, Oral cancer, Arsenic toxicity, West Bengal

Funding: the work was supported by Department of Science and Technology INSPIRE Fellowship 2013-2014, New Delhi. Research fellow: Pritha Pal, M.Sc.

Received: September 28, 2015. Accepted: March 1, 2016.

Corresponding author: P. Pal, Vivekananda Institute of Medical Sciences, Department of Genetics, 99 Sarat Bose Road, Kolkata 700026, India (e-mail: pritha.mcbt@gmail.com). 


\section{INTRODUCTION}

Oral carcinoma $(\mathrm{OC})$ is a much discussed problem nowadays worldwide, occurring more amongst males. Its rate of incidence in India is 12.6 per 100000 populations, the data being age-standardized [1]. The main risk factors of this disease, being intake of tobacco (smoking and smokeless), betel quid and human papilloma virus (HPV) infection account for $43 \%$ of the total number of deaths. But those behavioral risk factors do not explain the high incidence of the OC, which may suggest the interference of other potent factors.

Heavy metal toxicity has been found to exert its impact on various diseases, sometimes even proving out to be carcinogenic. These metals include lead, nickel, arsenic, cadmium, etc., the presence of which in soils might have toxic effects on human health by means of intake of food growing on them [2]. Arsenic exposure leading to skin, lung and bladder cancer has already been established [3]. Moreover, certain regions of Taiwan have reported to have a higher incidence of the oral carcinoma [2], the cause being arsenic exposure. Arsenic toxicity effect may be detected through the cytogenetic damage in the form of chromosomal anomalies, micronuclei, sister chromatid exchanges, which occur due to the genotoxic effect of arsenic to the superfamily of ubiquitous multifunctional enzymes, namely glutathione-S-transferases. Those enzymes are involved in cellular detoxification, and genetic variants are created by this heavy metal.

Since the State of West Bengal in India is reported to have high content of arsenic in its groundwater [4,5], we have included this region in our study in order to find out if there is any possible link between this metal toxicity in the oral carcinoma. This is a case control study carried out in our hospital in order to compare the arsenic (As) concentration in hair samples, frequency of micronuclei in buccal smear of patients - with those in the control population.

\section{MATERIAL AND METHODS}

\section{Study sample}

In this prospective study, a stratified sampling method was used for selecting 157 participants (54 oral malignant (OM), 53 oral premalignant (OPM), and 50 control) who were asked about their daily lifestyle habits and epidemiological data, after having taken their proper consent. A total of 30785 patients were screened in the Outpatient Departments of the ENTHead and Neck Surgery, Oral \& Maxillofacial Surgery of our hospital. Among these, 54 patients with histopathologically confirmed the cases of oral carcinoma, 53 with premalignant oral lesions and conditions were recruited for this study between November 2012 and July 2015.

Adults with non-treated frank and premalignant oral and oropharyngeal squamous carcinoma as well as control individuals, exposed/not exposed to arsenic toxicity were included in the study. Whereas we did not include pediatric patients, advanced oral malignant cases, cases with other oral lesions and post treatment cases. All cases were newly diagnosed. All were residents of various districts of West Bengal.

Fifty controls (cancer free) were recruited concurrently from the group of the patients residing in the similar geographic area. Controls were selected from among the relatives of the cases who accompanied them and stayed in the same localities. Age distribution for the controls was comparable to that of the cases.

Cases and controls were matched primarily by the frequency of geographic and social origin and secondly by the age distribution. They mostly belong to medium to low economic classes having the similar lifestyle and level of education.

\section{Ethics}

The study was ethically cleared by our respective institutional committee. 


\section{Questionnaire}

The demographic data of the concerned subjects was collected (age, gender and residential history). Data of the extent of arsenic contamination in various blocks/wards of the districts of this state was obtained from literature [6].

\section{Sample collection and analysis}

Buccal smear and hair samples were collected after having obtained informed consents from all the subjects. The collected 54 malignant, 53 premalignant and 50 control hair samples were treated by the method of flow injection-hydride generation-atomic absorption spectrometry for proper arsenic count and their buccal smears were taken on slides, Pap stained and examined under the microscope for detecting the presence of micronuclei and apoptosis.

\section{Statistics}

The statistical analysis was performed comparing the cases with malignant and premalignant oral lesions to the control on the basis of demographic factors, arsenic level in hair samples and the presence of micronuclei and apoptosis in buccal smear. A Student's t-test was used for comparing the case and control groups for arsenic

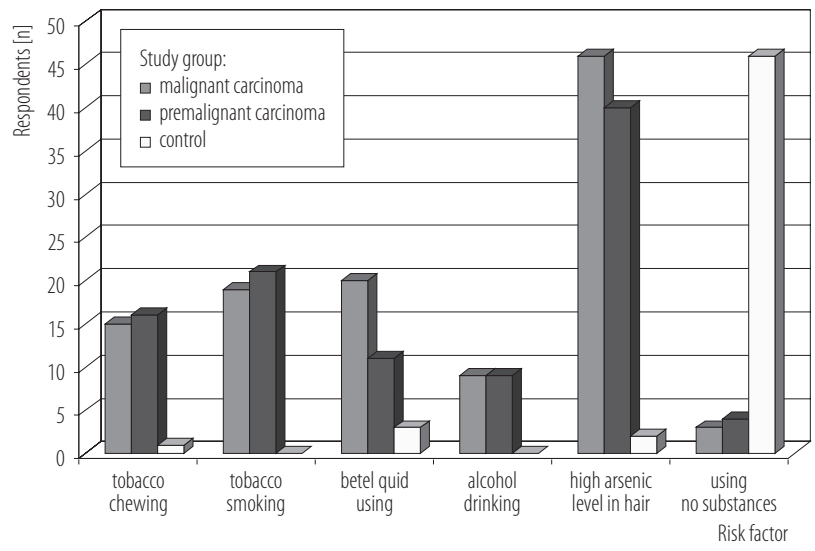

Fig. 1. Relationship between risk factors and oral/ oropharyngeal carcinoma in West Bengal, 2012-2015

level in hair. The arsenic (As) level mean, standard deviation (SD), quartiles and medians for all these groups were calculated. The statistical analysis was done using GraphPad prism software. Every test was 2-sided with a level of $\mathrm{p}$ value $<0.05$, which proved to be significant.

\section{RESULTS}

The Figure 1 shows the overall association of various risk factors with the patients and controls. The age-sex distribution, source of drinking water and the various risk factor associations is depicted in the Table 1.

Table 1. Respondents' characteristics in the study of arsenic exposure in oral/oropharyngeal carcinoma in West Bengal, 2012-2015

\begin{tabular}{|c|c|c|c|}
\hline \multirow{3}{*}{ Characteristics } & \multicolumn{3}{|c|}{$\begin{array}{c}\text { Study group } \\
(\mathrm{N}=157) \\
{[\mathrm{n}]}\end{array}$} \\
\hline & \multicolumn{2}{|c|}{ carcinoma } & \multirow{2}{*}{$\begin{array}{c}\text { control } \\
(\mathrm{N}=50)\end{array}$} \\
\hline & $\begin{array}{c}\text { malignant } \\
(\mathrm{N}=54)\end{array}$ & $\begin{array}{c}\text { premalignant } \\
(\mathrm{N}=53)\end{array}$ & \\
\hline \multicolumn{4}{|l|}{$\overline{\operatorname{Sex}}$} \\
\hline males & 38 & 39 & 37 \\
\hline females & 16 & 14 & 13 \\
\hline \multicolumn{4}{|l|}{ Age } \\
\hline $15-35$ years & 11 & 13 & 12 \\
\hline $36-55$ years & 35 & 33 & 32 \\
\hline $56-75$ years & 8 & 7 & 6 \\
\hline
\end{tabular}


Table 1. Respondents' characteristics in the study of arsenic exposure in oral/oropharyngeal carcinoma in West Bengal, 2012-2015 - cont.

\begin{tabular}{|c|c|c|c|}
\hline \multirow{3}{*}{ Characteristics } & \multicolumn{3}{|c|}{$\begin{array}{c}\text { Study group } \\
(\mathrm{N}=157) \\
{[\mathrm{n}]}\end{array}$} \\
\hline & \multicolumn{2}{|c|}{ carcinoma } & \multirow{2}{*}{$\begin{array}{c}\text { control } \\
(\mathrm{N}=50)\end{array}$} \\
\hline & $\begin{array}{c}\text { malignant } \\
(\mathrm{N}=54)\end{array}$ & $\begin{array}{l}\text { premalignant } \\
\quad(\mathrm{N}=53)\end{array}$ & \\
\hline \multicolumn{4}{|l|}{ Drinking water } \\
\hline mineral water & 1 & 1 & 1 \\
\hline \multicolumn{4}{|c|}{ municipality corporation } \\
\hline direct & 20 & 21 & 20 \\
\hline treated & 15 & 13 & 12 \\
\hline \multicolumn{4}{|l|}{ tube well } \\
\hline \multicolumn{4}{|l|}{ deep } \\
\hline direct & 10 & 11 & 10 \\
\hline treated & 0 & 0 & 0 \\
\hline \multicolumn{4}{|l|}{ shallow } \\
\hline direct & 7 & 6 & 6 \\
\hline treated & 0 & 0 & 0 \\
\hline \multicolumn{4}{|l|}{ pond water } \\
\hline direct & 0 & 0 & 0 \\
\hline treated & 1 & 1 & 1 \\
\hline \multicolumn{4}{|l|}{ Addiction* } \\
\hline betel quid using & 20 & 12 & 4 \\
\hline tobacco chewing & 14 & 17 & 1 \\
\hline tobacco smoking & 20 & 22 & 0 \\
\hline alcohol drinking & 9 & 9 & 0 \\
\hline using no substances & 3 & 4 & 46 \\
\hline
\end{tabular}

* Some of the malignant and premalignant cases and control individuals have $>1$ addiction.

The State of West Bengal is having 3 zones of districts and wards, based on the extent of arsenic contamination. Highly affected districts include 107 blocks and 30 wards affected out of 149 blocks in 8 districts and 100 wards of Kolkata. Mildly affected districts include 4 blocks affected out of 29 blocks in 5 districts. Unaffected districts include no affected ones out of 63 blocks in 5 districts [6].

A total of 103 out of 107 cases have reported the highly affected districts being their origin and the remaining 4 came from unaffected areas of this state. 


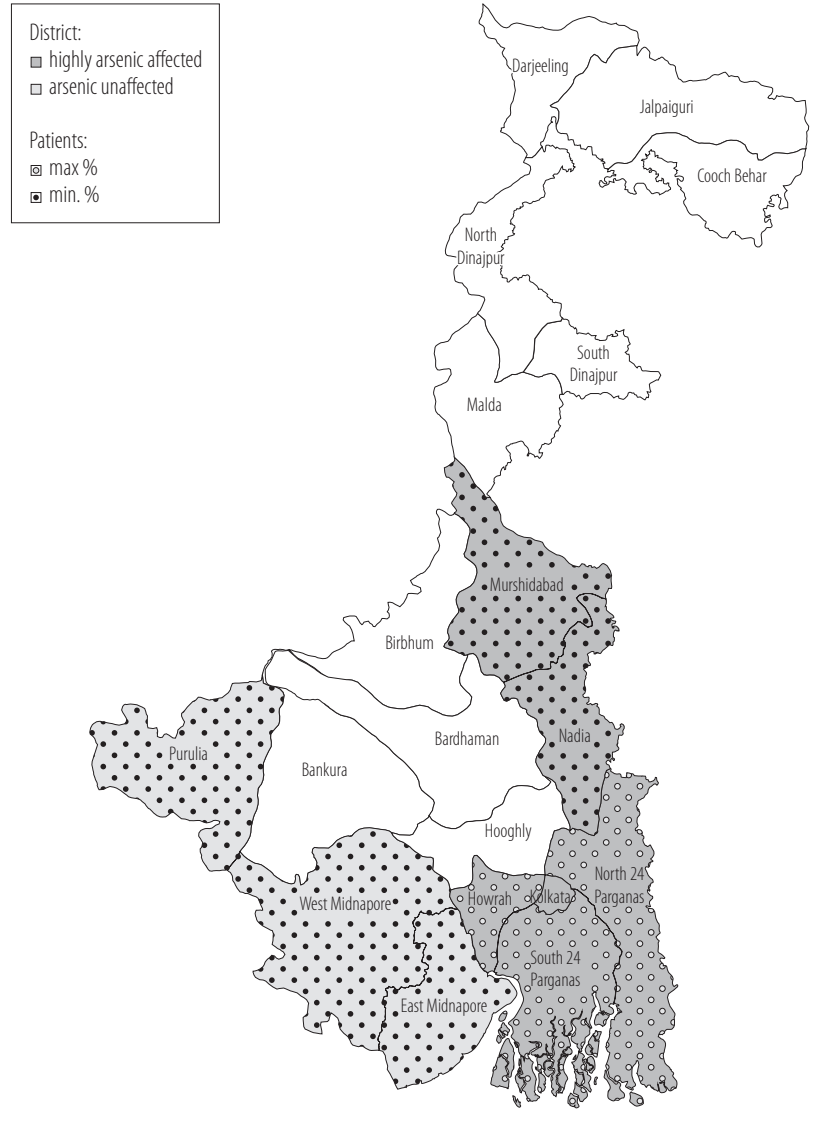

Fig. 2. Arsenic exposure and patients with oral/oropharyngeal carcinoma in West Bengal, 2012-2015
The data relating to the highly arsenic affected and unaffected districts of West Bengal and the data of the geographic distribution of the patients coming from those districts are depicted in the map of West Bengal (Figure 2). The tabular comparison is illustrated in the Table 2.

The distribution of As level in hair samples of cases and control is shown in the Table 3, which includes the mean, SD, medians, range and the quartiles. Out of 107 cases, 81.3\% showed their arsenic count above the safe limit $(0.8 \mu \mathrm{g} / \mathrm{g})$ whereas $96 \%$ of the controls' arsenic count was within the safe limit. This is shown in the Table 4 and Figure 3.

There is a significant difference of the micronuclei frequency between the cases and controls (Table 5). In our study we have found no significant correlation between the As content in hair and micronuclei frequency in the malignant as well as premalignant patients whereas Spearman's r value is found to be 0.116 and 0.19 , respectively. In both the malignant and premalignant cases, distribution was found to be non-parametric by Kolmogorov-Smirnov test. One case and all the controls showed the presence of apoptosis. The micronuclei and apoptosis may be clearly seen through the Photo 1a and 1b, respectively.

Table 2. Arsenic highly affected and unaffected districts of West Bengal and patients with oral/oropharyngeal carcinoma, 2012-2015

\begin{tabular}{lcc}
\hline \multicolumn{1}{c}{$\begin{array}{c}\text { Extent of arsenic exposure } \\
\text { and district in West Bengal }\end{array}$} & $\begin{array}{c}\text { Patients with oral/oropharyngeal carcinoma } \\
(\mathrm{N}=107) \\
{[\%]}\end{array}$ & $\begin{array}{c}\text { Arsenic affected blocks } \\
(\mathrm{N}=241) \\
{[\%]}\end{array}$ \\
\hline $\begin{array}{l}\text { Highly affected } \\
\text { Nadia }\end{array}$ & 2 & 100.0 \\
North 24 Parganas & 17 & 95.4 \\
Murshidabad & 2 & 92.3 \\
South 24 Parganas & 14 & 64.7 \\
Howrah & 12 & 58.3 \\
Kolkata & 45 & 30.0 \\
Unaffected & & \\
Purulia & 2 & 0.0 \\
Midnapur (East) & 4 & 0.0 \\
Midnapur (West) & 2 & 0.0 \\
\hline
\end{tabular}


Table 3. Arsenic concentration in respondents' hair in West Bengal, 2012-2015

\begin{tabular}{|c|c|c|c|c|c|c|c|}
\hline \multirow[t]{2}{*}{ Study group } & \multirow{2}{*}{$\begin{array}{c}\text { Respondents } \\
(\mathrm{N}=157) \\
{[\mathrm{n}]}\end{array}$} & \multicolumn{6}{|c|}{$\begin{array}{l}\text { Arsenic concentration in hair } \\
{[\mu \mathrm{g} / \mathrm{g}]}\end{array}$} \\
\hline & & $\mathrm{M} \pm \mathrm{SD}$ & 25-75th percentile & range & $\mathrm{Me}$ & $95 \% \mathrm{CI}$ of $\mathrm{M}$ & $\mathrm{p}$ \\
\hline Malignant carcinoma & 54 & $2.071 \pm 1.102$ & $1.170-2.615$ & $0.72-4.78$ & 1.88 & $1.616-2.526$ & $<0.001^{*}$ \\
\hline Premalignant carcinoma & 53 & $1.746 \pm 1.067$ & $0.935-2.520$ & $0.39-4.23$ & 1.45 & $1.306-2.187$ & $<0.001^{*}$ \\
\hline Control & 50 & $0.544 \pm 0.110$ & $0.440-0.630$ & $0.40-0.76$ & 0.52 & $0.513-0.576$ & $<0.001^{*}$ \\
\hline
\end{tabular}

$\mathrm{M}$ - mean; SD - standard deviation; Me - median; CI - confidence interval.

* The difference of mean values between the control group and case (premalignant and malignant) group with reference to arsenic count is highly significant.

Table 4. Oral/oropharyngeal carcinoma and arsenic level in respondents' hair in West Bengal, 2012-2015

\begin{tabular}{lcccccc}
\hline \multirow{2}{*}{\multicolumn{1}{c}{ Study group }} & \multicolumn{5}{c}{$\begin{array}{c}\text { Respondents with different arsenic level in hair } \\
(\mathrm{N}=157) \\
{[\mathrm{n}]}\end{array}$} \\
\cline { 2 - 7 } & total & $\begin{array}{c}\leq 0.8 \mu \mathrm{g} / \mathrm{g} \\
\text { (safe limit) }\end{array}$ & $0.81-1.8 \mu \mathrm{g} / \mathrm{g}$ & $1.81-2.8 \mu \mathrm{g} / \mathrm{g}$ & $2.81-3.8 \mu \mathrm{g} / \mathrm{g}$ & $\geq 3.81 \mu \mathrm{g} / \mathrm{g}$ \\
\hline Malignant carcinoma & 54 & 6 & 23 & 14 & 7 & 4 \\
Premalignant carcinoma & 53 & 14 & 22 & 11 & 4 & 2 \\
Control & 50 & 48 & 2 & 0 & 0 & 0 \\
\hline
\end{tabular}

Table 5. Micronuclei frequency in buccal smear of respondents in the study of arsenic exposure in oral/oropharyngeal carcinoma in West Bengal, 2012-2015

\begin{tabular}{|c|c|c|c|}
\hline \multirow[t]{2}{*}{ Variable } & \multicolumn{2}{|c|}{$\begin{array}{l}\text { Study group } \\
(\mathrm{N}=157) \\
\text { (range) } \\
{[\%]}\end{array}$} & \multirow[t]{2}{*}{$\mathrm{p}$} \\
\hline & $\begin{array}{l}\text { premalignant and malignant } \\
\text { carcinoma }\end{array}$ & control & \\
\hline Micronuclei frequency & $0.1-1.5$ & $0.0-0.1$ & $<0.05^{*}$ \\
\hline
\end{tabular}

* The difference of mean values of micronuclei frequency with reference to cases and control groups is significant.

\section{DISCUSSION}

The level of heavy metal exposure to the human body is said to arise from its elevated content in soil [7]. Longtime intake of water containing these metals may come out with toxic outcomes in different parts of our body. Studies related to this kind of heavy metal exposures turning out to be carcinogenic have been carried out in many places of Taiwan [8], Greece, etc. Prominent consequences in the form of cytogenetic damage have been reported from acute and chronic arsenic toxicity in various countries like Mexico, Finland, Argentina, etc. [9]. Arsenic involvement in the mutation of glutathione-S-transferases hampering the cellular detoxification may be detected through assays of chromosomal abnormalities and micronuclei [9]. 


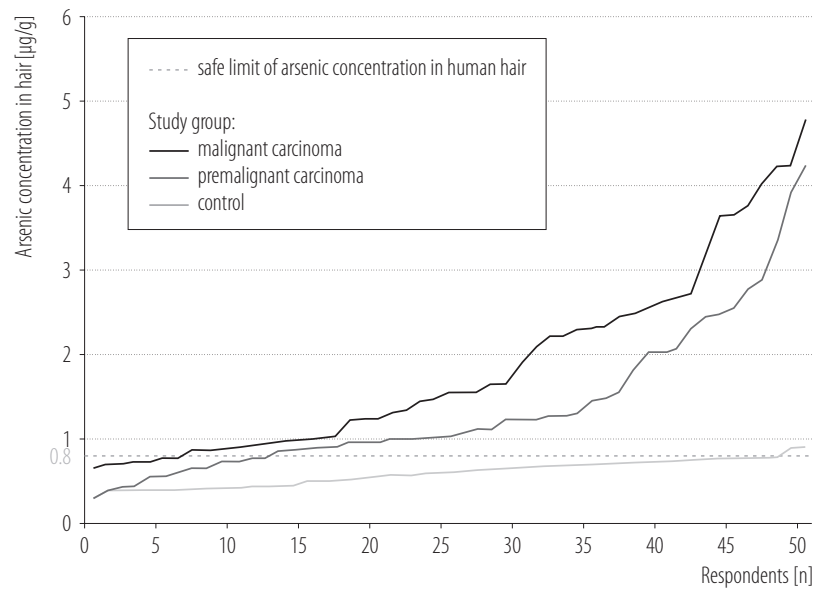

Fig. 3. Comparison of arsenic concentration in respondents hair in West Bengal, 2012-2015

West Bengal (India) and Bangladesh are the 2 worst arsenic affected areas in the world. In those 2 regions, the arsenic source being mainly geological contaminates aquifers which provide water to over 1 million tube-wells. About 42.7 million individuals in 9 districts of West Bengal are exposed to ground water arsenic concentration which is above the maximum permissible limit of $50 \mu \mathrm{g} / \mathrm{l}$. The arsenic accumulation in the Bengal Delta Plain is supposed to have taken place during the Holocene age with alluvial sediments containing arsenic, which have been deposited by the rivers Ganga, Brahmaputra, Meghna and other smaller rivers flowing across this plain into the Bay of Bengal.

The overall As content in the farm soil of contaminated areas of the selected region has profound negative impacts on nearby residents. The association between heavy metals residing in the environment and those inside the human body may be detected through their high concentrations in blood, urine and hair. Since arsenic toxicity is well established in the causation of skin, lung and bladder cancer [10] we have carried out this study in order to find its direct or indirect involvement in oral carcinoma, the latter being highly incident nowadays in this population.

Like all other carcinoma, oral cancer also results from various mutations and chromosomal abnormalities in genes
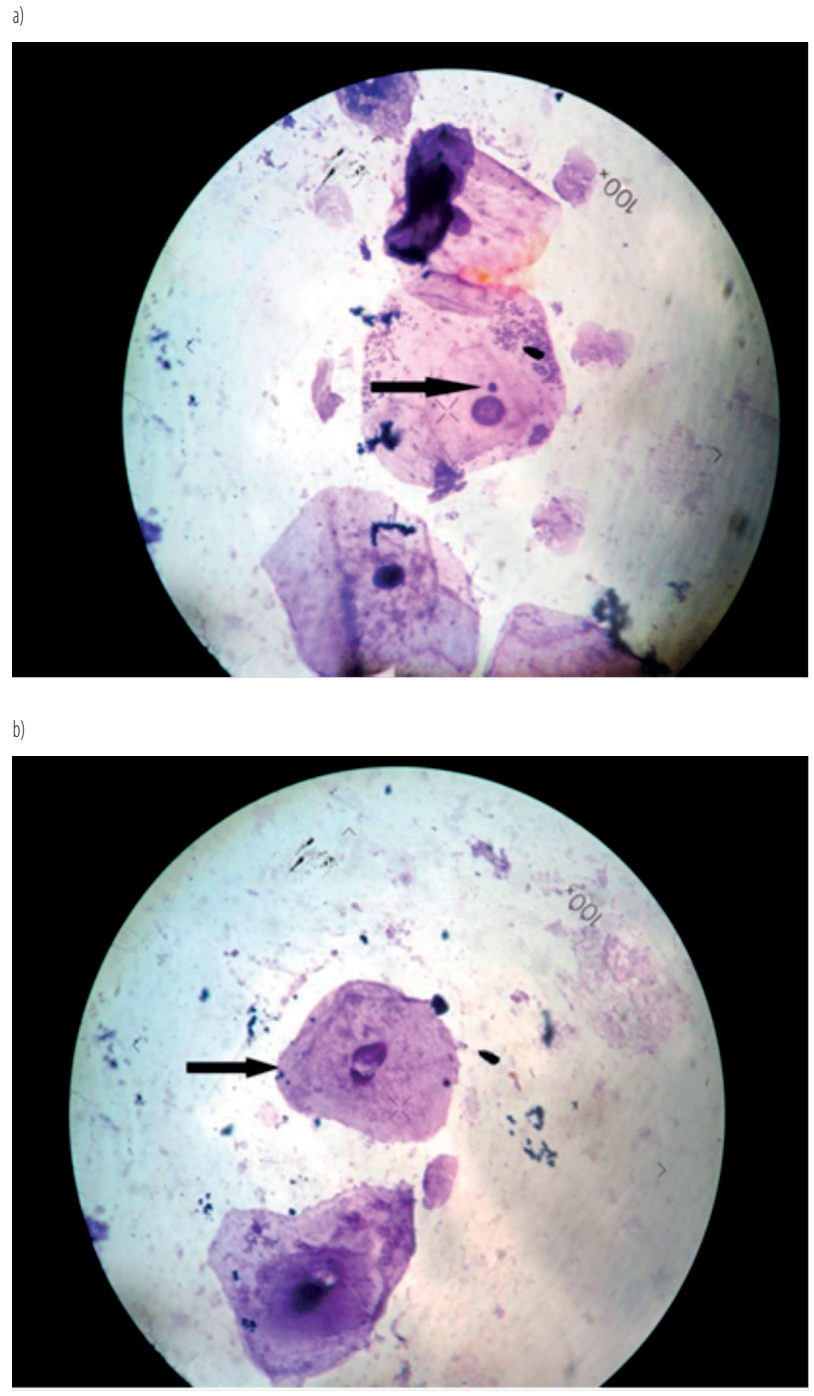

Arrows indicates: a) micronuclei, b) an apoptotic cell.

Photo 1. Papanicolaou-stained buccal cells (100 $\times$ magnification) of respondents in the study of arsenic exposure in oral/ oropharyngeal carcinoma in West Bengal, 2012-2015

controlling the cell cycle and deoxyribonucleic acid (DNA) repair [11]. So, various cytogenetic tests including the micronucleus test in addition to tests of various degenerative alterations indicative of apoptosis (karyorrhexis, pyknosis, and condensed chromatin), which examines the presence of micronuclei, absence of apoptosis and presence of any chromosomal anomaly under microscope, give a promising method to detect the occurrences of cytogenetic alterations 
in the oral epithelium due to this carcinoma [12]. The authors observed $\mathrm{MN}$ frequencies in exfoliated buccal cells in normal mucosa, precancerous lesions and squamous cell carcinoma of Indian subjects and concluded that the MN frequency may be a marker of epithelial carcinogenic progression [13]. However, no correlational studies between the cytogenetic damage imposed by the oral carcinoma and the arsenic toxicity have yet been performed, making this study more novel in its own stand.

In this study we have provided direct evidence of a possible correlation between As toxicity and oral malignant and premalignant lesions by examining metal levels in hair samples. Oral malignant and OPM cases' hair samples' As concentration were higher than the controls' ones on a significant level as shown in the Table 4. In this study, the difference of micronuclei and apoptosis frequency between cases and controls is also found to be significant. On the contrary to our findings, a recent study in central Taiwan revealed the absence of significant association between As blood levels and oral malignant and premalignant lesions [14]. However, previous studies [15-18] found positive associations between this metal and risk of various types of cancers. No correlation between the micronuclei frequency and arsenic count among cases as observed in this study may nullify the fact of estimating the extent of this metal toxicity in terms of the MN assay, in the case of the oral squamous cell carcinoma. However, the sample size being small enough, a higher population size is required to make this correlation statistically more significant and reach a proper conclusion.

The use of soil As concentration data relating to each patient does not actually indicate the true environmental exposure, which acts as a limitation of this study. Nonetheless, the As concentration in the farm soil may somewhat reflect the amount of As in the environment and also the risk that the residents in the vicinity are exposed to, since soil may be regarded as both an emitter and a receiver of the environmental toxin.

\section{CONCLUSIONS}

This study has come out with useful findings indicating the environmental effects on human health. The results show that the arsenic concentration in the hair samples of the cases is comparatively higher than those found in the control group, although the limitation lies in the sample size. This may infer a possible relation between the metal toxicity and oral malignancy in this population. Although the higher number of cases have their origin in highly arsenic affected districts of West Bengal, a few patients also came from the unaffected districts. This may indicate the involvement of the main risk factors of this disease.

Yet a larger sample size and extensive statistical analysis are required for detailed and comprehensive investigations. This may help us in risk assessment and policy development in order to protect general human health, particularly in developing countries where public concern towards these issues is limited.

\section{ACKNOWLEDGMENTS}

We are grateful to the Secretary of Ramakrishna Mission Seva Pratishthan Swami Satyadevananda to kindly allow us to conduct the study in this institution.

\section{REFERENCES}

1. Petersen PE. The World Oral Health Report 2003: Continuous improvement of oral health in the 21st century - The approach of the WHO Global Oral Health Programme. Geneva: World Health Organization; 2003.

2. Navarro Silvera SA, Rohan TE. Trace elements and cancer risk: A review of the epidemiologic evidence. Cancer Causes Control. 2007;18(1):7-27, https://doi.org/10.1007/s10552-006-0057-z.

3. Guha Mazumder DN. Chronic arsenic toxicity and human health. Indian J Med Res. 2008;128(4):436-47.

4. Patra M, Halder A, Bhowmick N, De M. Use of black tea in modulating clastogenic effects of arsenic in mice in vivo, West Bengal, India. J Environ Pathol Toxicol Oncol. 2005;24(3): 201-10, https://doi.org/10.1615/JEnvPathToxOncol.v24.i3.60. 
5. Das D, Samanta G, Mandal BK, Chowdhury TR, Chanda CR, Chowdhury PP, et al. Arsenic in ground water in six districts of West Bengal, India. Environ Geochem Health. 1996;18:5-15, https://doi.org/10.1007/BF01757214.

6. Chakraborti D, Das B, Rahman MM, Chowdhury UK, Biswas B, Goswami AB, et al. Status of groundwater arsenic contamination in the state of West Bengal, India: A 20-year study report. Mol Nutr Food Res. 2009;53(5):542-51, https:// doi.org/10.1002/mnfr.200700517.

7. LI Y, Wang YB, Gou X, Su YB, Wang G. Risk assessment of heavy metals in soils and vegetables around non-ferrous metals mining and smelting sites, Baiyin, China. J Environ Sci. 2006; 18(6):1124-34, https://doi.org/10.1016/S1001-0742(06)60050-8.

8. Su CC, Lin YY, Chang TK, Chiang CT, Chung JA, Hsu YY, et al.. Incidence of oral cancer in relation to nickel and arsenic concentrations in farm soils of patients' residential areas in Taiwan. BMC Public Health. 2010;10:67, https://doi.org/ 10.1186/1471-2458-10-67.

9. Ghosh P, Basu A, Mahata J, Basu S, Sengupta M, Das J, et al. Cytogenetic damage and genetic variants in the individuals susceptible to arsenic-induced cancer through drinking water. Int J Cancer. 2006;118(10):2470-8, https://doi.org/ 10.1002/ijc.21640.

10. Saha JC, Dikshit AK, Bandyopadhyay M, Saha KC. A review of arsenic poisoning and its effects on human health. Crit Rev Environ Sci Technol. 1999;29(3):281-313, https://doi. org/10.1080/10643389991259227.

11. Holland N, Bolognesi C, Kirsch-Volders M, Bonassi S, Zeiger E, Knasmueller S, et al. The micronucleus assay in human buccal cells as a tool for biomonitoring DNA damage: The HUMN project perspective on current status and knowledge gaps. Mutat Res. 2008;659(1-2):93-108, https:// doi.org/10.1016/j.mrrev.2008.03.007.
12. Kingsley K, O'Malley S, Ditmyer M, Chino M. Analysis of oral cancer epidemiology in the US reveals statespecific trends. BMC Public Health. 2008;8:87, https://doi. org/10.1186/1471-2458-8-87.

13. Stich HF, Curtis JR, Parida BB. Application of the micronucleus test to exfoliated cells of high cancer risk groups: Tobacco chewers. Int J Cancer. 1982;30(5):553-9, https://doi. org/10.1002/ijc.2910300504.

14. Yuan TH, Lian IB, Tsai KY, Chang TK, Chiang CT, Su CC, et al. Possible association between nickel and chromium and oral cancer: A case-control study in central Taiwan. Sci Total Environ. 2011;409(6):1046-52, https://doi.org/10.1016/j.scitotenv.2010.11.038.

15. Kazi TG, Wadhwa SK, Afridi HI, Kazi N, Kandhro GA, Baig JA, et al. Interaction of cadmium and zinc in biological samples of smokers and chewing tobacco female mouth cancer patients. J Hazard Mater. 2010;176(1-3):985-91, https:// doi.org/10.1016/j.jhazmat.2009.11.139.

16. Su CC, Lin YY, Chang TK, Chiang CT, Chung JA, Hsu YY, et al. Incidence of oral cancer in relation to nickel and arsenic concentrations in farm soils of patients' residential areas in Taiwan. BMC Public Health. 2010, https://doi. org/10.1186/1471-2458-10-67.

17. Wadhwa SK, Kazi TG, Afridi HI, Kazi N, Kandhro GA, Baig JA, et al. Evaluation of cadmium and zinc in biological samples of tobacco and alcohol user male mouth cancer patients. Hum Exp Toxicol. 2010;29(3):221-30, https://doi. org/10.1177/0960327109360045.

18. Feki-Tounsi M, Olmedo P, Gil F, Khlifi R, Mhiri MN, Rebai A, et al. Cadmium in blood of Tunisian men and bladder cancer: Interactions with arsenic exposure and smoking. Environ Sci Pollut Res Int. 2013;20(10):7204-13, https://doi. org/10.1007/s11356-013-1716-8.

This work is available in Open Access model and licensed under a Creative Commons Attribution-NonCommercial 3.0 Poland License - http://creativecommons.org/ licenses/by-nc/3.0/pl/deed.en. 